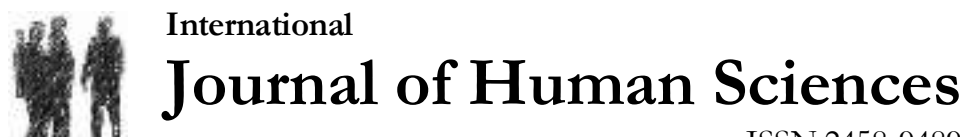 \\ ISSN:2458-9489
}

Volume 14 Issue 3 Year: 2017

\section{Determining the opinions of physical education teacher candidates about using concept cartoons in education}

\author{
Hande İnan ${ }^{1}$ \\ Metin Kaya ${ }^{2}$
}

\begin{abstract}
In this study, which emphasizes on the importance of using concept cartoons in education, the opinions of physical education teacher candidates about volleyball including in the program of physical education were detected through concept cartoons. This study which is a qualitative research, was conducted with the participation of 60 physical education teacher candidates studying in the $4^{\text {th }}$ year in the Physical Education and Sports High School in Adiyaman University. As data collecting tool, a form including in a cartoon about volleyball and 6 open-ended questions about this concept cartoon in the study was used. The question form used was performed to determine the opinions of physical education teacher candidates about using cartoons in education. These data were studied through content analysis. At the result of the study, it was concluded that the opinions of physical education teacher candidates about concept cartoons used in education are positive and concept cartoons influence learning in a positive way and provide motivation and academic success in lessons.
\end{abstract}

Keywords: Volleybol, Cartoon, Physical Education Teacher Candidates, Physical Education

\section{Introduction}

The purpose of constantly changing teaching programs is to provide not a teachercentered but a learner-centered mode of organization and to reveal a mechanism aiming the learners to be trained better. Therefore, by considering that each student has different learning styles, learning circles should be arranged according to the students in order to reach the acquisitions included in the educational programs. The most important element is the teaching materials. Choosing proper teaching materials will increase in the productivity of the lessons and using visual tools and forms such as schemes and graphics will play an important role in teaching acquisitions to the learners.

Visual messages are more permanent in learning compared with reading. Images will keep people's interest and attention alive. Based on this, it shows that using concept cartoons in education today will give rise to successful outcomes. Since concept cartoon is not only a visual tool but it also includes humour, it has an important place in terms of learning-teaching. It can be defined that concept cartoon is the description of the thought in association with humour and in harmony with drawings (Akkaya,2011:49). It is stated that since cartoon contains homour

\footnotetext{
${ }^{1}$ Instructor, Adiyaman University School of Physical Education and Sport, Department of physical education teaching, hinan@adiyaman.edu.tr

2 Professor Dr., Gazi University Faculty of Sport Sciences, Department of physical education teaching, mkaya@gazi.edu.tr
} 
İnan, H., \& Kaya, M. (2017). Determining the opinions of physical education teacher candidates about using concept cartoons in education. Journal of Human Sciences, 14(3), 2666-2676. doi:10.14687/ihs.v14i3.4506

elements, it has some outcomes such as forcing think, imagining and revealing creativity. Concept cartoons provide many benefits in the presentation of new information, ideas, concepts and behaviours (Roesky and Kennepohl, 2008).

Teachers' teaching at schools by using concept cartoons about the sunjects will drammatically contribute in improving students' thinking skills about the lesson. Cartoons could be utilized in the activities conducted in classes.

According to Akkaya, the classifications of the concept cartoons to be used in education are as such:

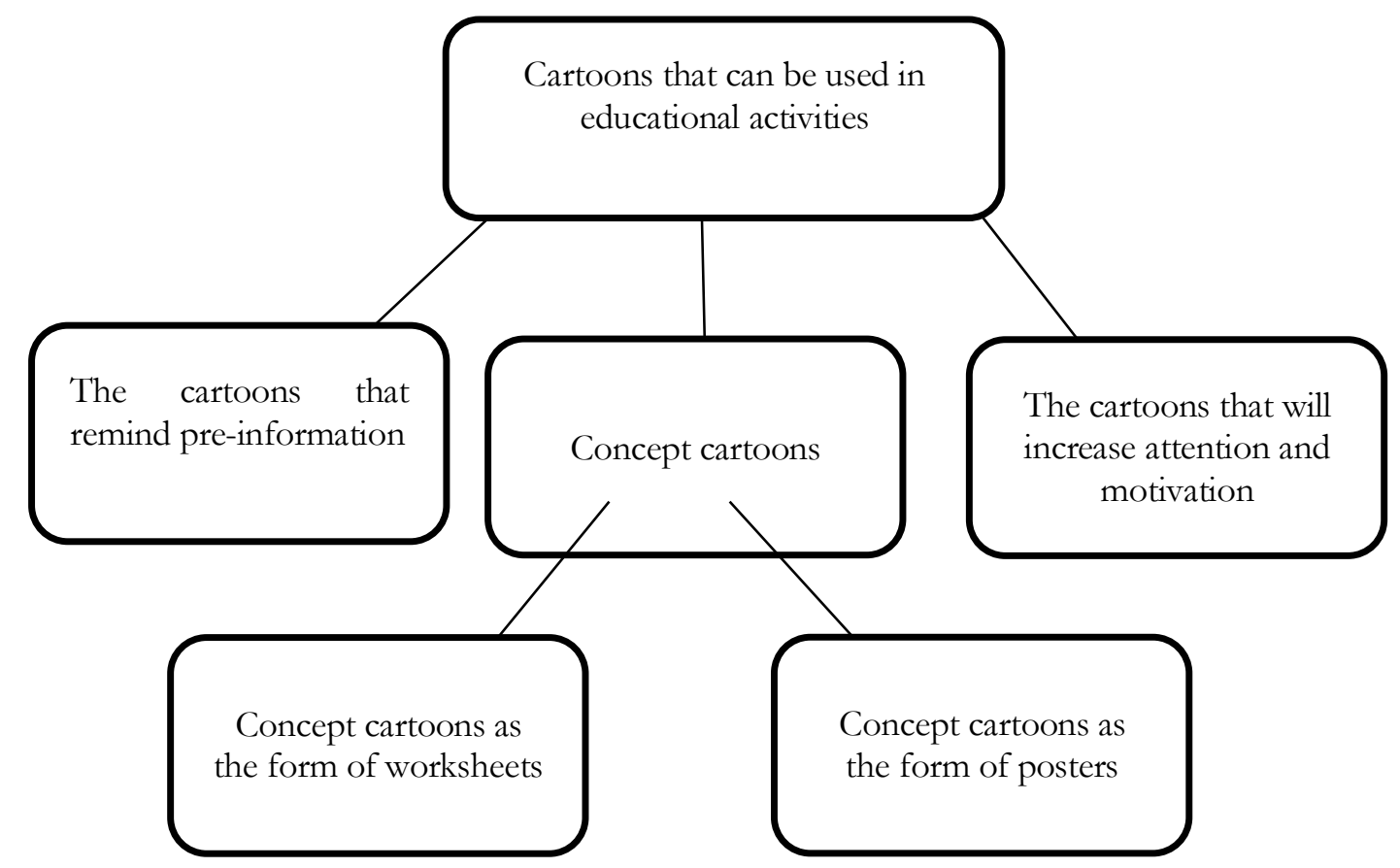

Sample events, question-answer activities, stories about the subject and concept cartoons can be included in the enhancement of teaching activities (Özer, 2004; Ören \& Meriç, 2014). When different methods, techniques and strategies are necessary to use, concept cartoons play important roles (Roesky \& Kennepohl, 2008). Concept cartoons were first designed and used by Naylor and McMurdo (1990). Contructivist learning approach which argues that information is interpreted and made up by individuals lies on its basis. (Morris, Merritt, Fairclough, Birrell \& Howitt, 2007: 42). The researchers define the concept cartoons as the expression of the discussion made by three or more characters with images. In the discussion, every one of the characters argues a different idea. One of the the ideas given in the discussion represents the thinking style which is acknowledged as scientifically true and others represent the thinking styles which are acknowledged scientifically not true but are made up by the students on their part. (Long and Marson, 2003: 22; Kabapinar, 2005: 136). Using concept cartoons as a method is as such: a concept cartoon prepared in the form of poster is hanged on a place in the class where all students can see. The teacher tells about the characters in the concept cartoon as well as what is needed to be told. Subsequently, the students are asked which one or ones of the characters' ideas they agree with and why. The students explain which one or ones of the characters' ideas they agree with. Thus, the thinking styles the students have turn out (Kabapinar, 2007: 258-259). There are two reasons for using concept cartoons: the first one is that the concept cartoons can readily start discussions within a class, so teacher doesn't need an extra attempt to make up a discussion atmosphere. The second one is that no matter which ideas they have, all students are able to use the same research method before teaching (Akkaya, 2011:61). Visual presentation skills of students could be improved through following specific disciplines (Flynt \& Brozo, 2010). Visual materials simplify the complex information, provide it to 
İnan, H., \& Kaya, M. (2017). Determining the opinions of physical education teacher candidates about using concept cartoons in education. Journal of Human Sciences, 14(3), 2666-2676. doi:10.14687/ihs.v14i3.4506

be learned more easily and facilitates it to be remembered afterwards. However, these materials do not show the same effect on all students. In order these materials to be effective, the students should know how to obtain information from these and learn the meaning of symbols and signs used (Özer, 2004).

The purpose in concept cartoon is the introducing the cartoon, discussing and studying about the thinking styles in the cartoon, and under the light of the information obtained recommenting the ideas in the cartoon. (Long and Marson, 2003; Flynt \& Brozo, 2010). In this frame, three factors influence on the success of teaching based on concept cartoons. The students are required to provide motivation and the concept cartoons should be presented as a teaching method by linking them with daily events in order to end up teaching with success and it was emphasized that the ideas should be chosen among those which were determined as a result of researches towards students' understanding and that thinking styles should be expressed through short and legible sentences as much as possible and the the style of expressions should have similarities (Morris, Merritt, Fairclough, Birrell and Howitt, 2007;21). It was pointed out that the concept cartoons in educational activities prepared like this would contribute to students' problem solving, crictical thinking, skills to produce scientific thinking and would help to concentrate by making the topic more attractive (Ören \& Meriç, 2014). In this context, the main purpose of the study was to determine what kind of contributions will bring when concept cartoons are used in teaching volleyball in physical education lessons.

With using concept cartoons in education, students could have a chance to discuss their ideas in social environments and in accordance with the discussions and opinions, they could evaluate their own cognitive situations and make revisions if necessary. Thus, they believe that learning with concept cartoons should be regarded as a social situation since they are used to improve the students' conceptual understanding and to show their conceptual situation (Stephenson \& Warwick, 2002). According to Keogh, Naylor and Wilson (1998) the concept cartoons have been used in primary school as well as in different stages of education in recent times. In literature research, the studies towards determining opinions of candidate teachers about concept cartoons in national and international levels are few in number and there is no study about the field of physical education. Therefore, this study needs to be conducted and it is aimed to determine the opinions of physical education teachers about volleyball (overarm pass, bump pass). In this respect, it is thought that the study will contribute to further studies in physical education.

\section{Method and material Study Design}

In this study, one of the qualitative research methods, a semi-structured interview form was used to determine opinions of physical education candidate teachers about concept cartoons. This study is a qualitative study and content analysis method was used for analyzing the data obtained from the study. Content analysis means a new renewable technique in which some words of a text are summarized with smaller categories by coding based on specific rules (Büyüköztürk, 2009: 269; cited by: Akkaya, 2012:409). A qualitative study is a study that shows preceptions and events in natural environments as realistic and total. It is an approach that takes understanding of social phenomenon within their own frames to the forefront with a perception that is based on making up theories. (Glaser,1978; cited by Yıldırım and Şimşek, 2013:45).

\section{Study group}

The study group of the research consists of 60 physical education teacher candidates, 40 males, 20 females, studying in $4^{\text {th }}$ class in the department of physical education teaching in the physical education and sports high school in Adiyaman University in the first term of 2016-2017 education year. 
İnan, H., \& Kaya, M. (2017). Determining the opinions of physical education teacher candidates about using concept cartoons in education. Journal of Human Sciences, 14(3), 2666-2676. doi:10.14687/ihs.v14i3.4506

\section{Data Collection and Analysis}

The data of the study were collected through a form including in 6 open-ended questions about the cartoon and the image of cartoon about volleyball prepared for the students studying in the $4^{\text {th }}$ class in the physical education and sports high school in Adiyaman University. The question form prepared was used to determine the students' opinion about the cartoon the students encountered with and it was preferred because it allowed the students a chance to give original answers. For the cartoons, an expert instructor was asked how the content validity was for the acquisitions and whether they are suitable for the students' level. The cartoons whose stories and speech bubbles were designed by the researcher were got drawn to a graphic designer. Initially, the experts' opinions from the faculty of education were taken to learn about whether the open-ended questions were suitable with the purpose of the researcher. After the experts found the questions as suitable for the study, the content validity of the questions in the form was designed according to the experts' views. 60 students answered the questions and the data of the study were obtained through these questions. Content analysis method was used for the analysis of the data of the study. The data obtained during the study were coded and with these codes, the statements of the teacher candidates were collected under specific themes by making up upper categories. Besides this, the data of the study were presented by supporting through the direct quotations from the statements of teacher candidates. Each teacher candidate was given a code (TC1: like teacher candidate 1) while making direct quotations in reporting, so that the participants could be kept confidential. At the end of the analysis, two experts were required to study the students' statements one by one. It was observed that two experts were generelly in agreement.

The questions about the cartoons are given below.

1. Have you ever come acroos any cartoon in physical education lessons?

2. What did you think of when you encountered with a cartoon in physical education lesson?

3. Was using cartoons in physical education lessons effective on your success? Why?

4. Did using cartoon in physical education lessons make the lessons entertaining? Why?

5. Were different visuals apart from cartoons used in physical education lessons? Why?

6. Would you like the cartoons to be used in other lessons? Why?

\section{Findings}

Under this title, the opinions of the teacher candidates about using cartoons in physical education lessons were quoted and commented and the frequency distributions were given.

Table 1: The opinions of the teacher candidates about the open-ended question "Have you ever come acroos any cartoon in physical education lessons?" and the frequency rates of these opinions.

\begin{tabular}{lc} 
Code & (f) \\
\hline Yes & 7 \\
No & 53 \\
Total & 60 \\
\hline
\end{tabular}

When table 1 was studied, most of the teacher candidates (53) said they had never come across with cartoons in the lessons before and other part of the students (7) said they came across with them in coursebooks before. However, none of the teacher candidates experienced lessons with cartoons in previous educational environments. At the result of the analysis of data obtained from the interviews, it could be said that majority of the candidates met with the concept cartoons in this practice for the first time. Some statements of the teacher candidates to 
İnan, H., \& Kaya, M. (2017). Determining the opinions of physical education teacher candidates about using concept cartoons in education. Journal of Human Sciences, 14(3), 2666-2676. doi:10.14687/ihs.v14i3.4506

the open-ended question "Have you ever come acroos any cartoon in physical education lessons?" are given as such:

"Yes, I came across" (TC55)

"No I haven't, but I would like to" (TC2)

"No, but it would be better to teach with cartoons" (TC4)

"Yes, I saw the cartoons in the coursebooks" (TC17)

Table 2: The opinions of the teacher candidates about the open-ended question "What did you think of when you encountered with a cartoon in physical education lesson?" and the frequency rates of these opinions.

Code (f)

\begin{tabular}{lc}
\hline Memorability & 3 \\
Boring & 4 \\
Nothing to think & 7 \\
Better teaching & 10 \\
Astonishment & 11 \\
Learning New things & 11 \\
More entertaining lessons & 14 \\
Total & 60 \\
\hline
\end{tabular}

In table 2, the overall of the teacher candidates (38) reported positive opinions, while 22 of them reported negative ones. The teacher candidates who reported positive opinions stated that physical education lessons would be more entertaining with cartoons, the subjects would be remembered easily, new things could be learnt and the teaching would be better. The students who reported negative opinions thought that the lessons would be more boring with cartoons. Some statements of the teacher candidates about the open-ended question "What did you think of when you encountered with a cartoon in physical education lesson?" are given as such:

"First, I didn't think of anything. Later I thought it would be fun". (TC54)

"At the beginning, I found it childish, but later I felt it was entertaining and memorable". (TC51)

"I thought it would be boring." (TC33)

"First I couldn't understand. Later I thought the teaching would be better." (TC11)

"I was surprised very much."(TC22)

"Nothing came to my mind" (TC60)

Table 3: The opinions of the teacher candidates about the open-ended question "Was using cartoons in physical education lessons effective on your success? Why?" and the frequency rates of these opinions.

Code (f)

Ineffectiveness

Reinforcing information

Remembering permanently

Increasing the interest in the lesson

Remembering the subjects easily 
İnan, H., \& Kaya, M. (2017). Determining the opinions of physical education teacher candidates about using concept cartoons in education. Journal of Human Sciences, 14(3), 2666-2676. doi:10.14687/ihs.v14i3.4506

According to table 3, the majority of the teacher candidates (54) reported positive opinions, while a part of them (6) stated negative ones. The students who reported positive views stated that they could easily remember the subjects with cartoons, their interest for the lessons increased and information about the subjects was reinforced. The candidate teachers who reported negative opinions stated that the cartoons had no effect on their success. Some statements of the teacher candidates about the open-ended question "Was using cartoons in physical education lessons effective on your success? Why?" are given as such:

"Yes they made me learn easier."(TC49)

"Yes. I always liked cartoons." (TC44)

"My interest to the lesson increased."(TC8)

"They were effective while learning the subjects I disliked." (TC5)

"They made me remind the subjects I have known easier." (TC27)

Table 4: The opinions of the teacher candidates about the open-ended question "Did using cartoon in physical education lessons make the lessons entertaining? Why?" and the frequency distributions of these views.

\section{Code}

(f)

Contributing to enjoy from the lessons

8

Facilitating learning 10

Avoiding from being commonplace

Spending more entertaining time

Having comic characters

Total

When table 4 was studied, all of the teacher candidates stated positive opinions and none of the students reported any negative opinion. Since all teacher candidates reported positive views, it was concluded that cartoons influenced the students in a positive way not only cognitively also affectively. Some statements of the teacher candidates about the open-ended question "Did using cartoon in physical education lessons make the lessons entertaining? Why?" are given as such:

"Yes. it facilitated my learning." (TC7)

"I liked because it included comic characters."(TC15)

"I was pleased that the cartoons aimed at being enjoyed from the lesson." (TC51)

"I didn't want the lesson to finish since it was a very enjoyable time."(TC56)

"The cartoons changed the mode of stereotype lessons." (TC9)

Table 5: The opinions of the teacher candidates about the open-ended question "Were different visuals apart from cartoons used in physical education lessons? Why?" and the frequency rates of the views.

Code

Picture

A photo about the branch

Comic book

19

Total

60 
İnan, H., \& Kaya, M. (2017). Determining the opinions of physical education teacher candidates about using concept cartoons in education. Journal of Human Sciences, 14(3), 2666-2676. doi:10.14687/jhs.v14i3.4506

When studied table 5, all of the teacher candidates reported their positive opinions. 12 of them stated pictures were used, 26 of them pointed out that a photo about the branch was used and 19 of them said comic books were used. None of the teacher candidates stated any negative opinion. The teacher candidates who reported positive opinions stated that pictures, photos about the branches and comic books could be used in physical education lessons. Some statements of the teacher candidates about the open-ended question "Were different visuals apart from cartoons used in physical education lessons? Why?" are as such:

"If pictures are used, it is more memorable." (TC12)

It attracts more when pictures about the subject taught are used. "(TC21)

"Using photos about branches provides students to concentrate on the subject." (TC34)

"If the photo of the sporter who are good at his own branch is used, the student enjoys more." (TC43)

"Just as a cartoon is used about sport, a comic book can be used in it as well." (TC1)

"I like comic books so much. I think that they can also be used as a visual." (TC19)

Table 6: The opinions of the teacher candidates about the open-ended question "Would you like the cartoons to be used in other lessons? Why?" and the frequency rates of these views

\section{Code}

Just suitable for this lesson

All lessons become more entertaining

More permanent in understanding the subjects 16

in all lessons

Using for the lessons based on memorization

Total

When table 6 was studied, the majority of the teacher canditates (51) reported positive opinions, whereas 9 of them reported negative opinions. The candidate teachers who reported positive opinions stated that using cartoons in all lessons would be entertaining, they should be used in the lessons based on memorization and they would be more permanent in understanding the subjects in all lessons. The teacher candidates who reported negative opinions thought that the cartoons would be suitable only for this lesson. Some statements of the teacher candidates about the open-ended question "Would you like the cartoons to be used in other lessons? Why?" are as such:

"Yes. All lessons. Just as physical education lessons become more enternaining, it would be so for all other lessons."'TC2)

"They should definitely be used in the lessons based on memorization. If used, there is no need to memorize and the learning will be more permanent." (TC23)

"They should only be used for physical education lesoons. They might not give pleasure in other lessons." (TC16)

"They should be used in all lessons since I thought they would provide a permanent learning." (TC3) 
İnan, H., \& Kaya, M. (2017). Determining the opinions of physical education teacher candidates about using concept cartoons in education. Journal of Human Sciences, 14(3), 2666-2676. doi:10.14687/jhs.v14i3.4506

\section{Discussion, Result and Suggestions}

It was concluded from the results of this study that the majority of teacher candidates had not encountered with cartoons in educational atmospheres before, the cartoons aroused positive feelings in teachers' candidates, the lessons became more entertaining and the learning subjects would become more permanent, photos about branches could be used instead of using cartoons and when used in other lessons, the cartoons would provide a more permanent learning. This situation shows that when cartoons are used in education, it will be effective in increasing the academic success in the lessons. Parallel to this study, in the studies of Öztürk and Özkan (2016), the opinions of class teacher candidates about natural disasters were taken through cartoons and it was concluded that using cartoon in teaching natural disasters would be productive. On the other hand, Oruç (2010) revealed that using humor not only contributes to the students' academic success but it also influences on their affectional process. Aksoy et.al (2010) in their study reached to a conclusion that using cartoon in Social Science Education increases the academic success. In the study of Ersoy and Türkkan (2010), it was concluded that it is possible to reveal misconceptions through cartoons. In other words, the message required to be transferred in education could be sent through cartoons. As in the results of the studies of Seçgin et.al (2010), cartoons should often be used as a teaching material in order to provide students to play an active role in teaching process and to improve their creative, analytical and interrogative skills. It was seen that there have been many findings of studies showing that concept cartoons keep students from traditional teaching aprooaches and instead they make education more distinctive (Birisci et.al, 2010; Kabapinar, 2005). As parallel to this study, in the studies of Ekici, Ekici \& Aydin (2007), a large part of the students stated positive opinions about concept cartoons and they liked concept cartoons. In the interviews, the students said they wanted concept cartoons to be used in other lessons as well so that the lessons would be funnier and more enjoyable, so they would understand the lesson better. In their studies, Keogh \& Naylor (2000) searched for theirs students' opinion about concept cartoons. At the end of the study, the students stated their opinion changed towards concept cartoons and the cartoons allowed them to learn their friends' thoughts and to discuss about these thoughts. In this respect, the findings obtained from the study show similarities with the studies of Keogh \& Naylor (2000) and those of Ekici, Ekici \& Aydin (2007). It was observed that as long as the cartoons drawn with the purpose of education are designed suitably, they can be used as an educational tool. In his study, Özel et.al. (2014) wanted teacher candidates to match or express 20 educational problems with 9 cartoons. It was seen that the candidates didn't caricaturise any educational problem except 20 educational issued given to them. Though Keogh et.al. (1998) saw negative evaluations with a rate of $47 \%$, they witnessed that these opinions shifted towards a scale of $97 \%$ positively at the beginning of the study. Finally, they said using cartoons would assist to think differently in understanding the subject and assessing the situation. As a result of this study in which the teachers' thoughts were quoted in detail, they said the cartoons would be a valuable method for teachers' usage. In his study, "Prospective Teachers' Opinions about Concept Cartoons Integrated with Modular Instructional Design", Cengizhan (2011) aimed to determine prospective teachers' opinions about modular instructional design in the lessons of professional teaching knowledge and about the usage of concept cartoons as a method in this design. At the end of the study, it was declared that all the participant teachers had a common view that concept cartoons influenced teaching positively, made the lessons attractive and provided motivation.

As a result of this, it was determined that the teacher candidates regarded using cartoons positively in the acquisitions of physical education lessons. 
İnan, H., \& Kaya, M. (2017). Determining the opinions of physical education teacher candidates about using concept cartoons in education. Journal of Human Sciences, 14(3), 2666-2676. doi:10.14687/ihs.v14i3.4506

\section{Result}

Based on the obtained findings, these results were found:

- It was proved that according to the teacher candidates, using cartoons in teaching subjects in physical education lessons are productive.

-It was concluded that using cartoons in physcial education lessons is a preferrable tool by the teacher candidates.

- It was found out that cartoon is an effective tool in conveying the required message to the students with the purpose of education.

The importance of using cartoons in education is increasing day by day. A cartoon can be used as a learning facilitator element in education.

\section{Suggestions}

Depending on these results, these suggestions could be given:

- The rate of using cartoons could be increased in training of teacher candidates.

- Teacher candidates could create awareness through cartoons about the question "How can I teach more productively and permanently?”

- Teacher candidates could be required to draw a cartoon about the subject. Using cartoons could be suggested in revealing the misconceptions

- Teachers help students to configurate information in their minds with contructivist approach. In order to provide the help, using cartoons in education could be suggested by combining them with student centered methods and techniques. The importance of using cartoons in student-centered education will increase further in the future.

\section{References}

Akkaya, A. (2011). Karikatürlerle dil bilgisi ögretimi, Yayınlanmış Doktora Tezi. Selçuk Üniversitesi, Eğitim Bilimleri Enstitüsü, Konya.

Akkaya, A. (2012). Öğretmen adaylarının konuşma sorunlarına ilişkin görüşleri, Mustafa Kemal University Journal of Social Sciences Institute, Year: 2012, Volume: 9, Issue: 20, s. 405-420

Aksoy, B., Karatekin, K., Kuş, Z. \& Sönmez, Ö.F. (2010). Sosyal bilgiler öğretiminde karikatür kullanımının öğrencilerin akademik başarısına etkisi. Newwsa, 5(4), 1484-1497.

Büyüköztürk, Ş. (2009). Bilimsel Arasttrma Yöntemleri. Ankara: Pegem A Yayıncllı.

Birisci, S., Metin, M. \& Karakaş, M. (2010). Pre-Service Elementary Teachers' Views on Concept Cartoons: A Sample from Turkey. Middle-East Journal of Scientific Research 5 (2): 91-97. URL: http://www.idosi.org/mejsr/mejsr5\%282\%29/7.pdf

Cengizhan, S. (2011). Moduiler Öğretim Tasarımılla Entegre Edilmiş Kavram Karikatürleri Hakkında Öğretmen Adaylarının Görüşleri. Eğgitim ve Bilim, 36 (160).

Christine, C., \& Lay-Yen, T. (2010). Using concept cartoon, pupils' drawings, and group discussions to tackle children's ideas about biological inheritance, Journal of Biological Education, 44:3, http://dx.doi.org/10.1080108-115, /00219266.2010.9656206.

Ekici, F., Ekici, E., \& Aydın, F. (2007). Utility of Concept Cartoons in Diagnosing and Overcoming Misconceptions Related to Photosynthesis. International of Joumal of Environmental \& Science Education, 2(4), 111-124.

Ersoy, A. F. \& Türkkan, B. (2010). İlköğretim öğrencilerinin çizdikleri karikatürlere yansıttıkları sosyal ve çevresel sorunların incelenmesi. Ë̆itim ve Bilim. 35(156), 96-109.

Flynt, E., S.,\& Brozo. W. (2010). Visual Literacy and the Content Classroom: A Question of Now, Not When. The Reading Teacher, 63(6), 526-528 DOI:10.1598/RT.63.6.11

Jones, M. G., \& Brader-Araje, L. (2002). The Impact of Constructivism on Education: Language, Discourse, and Meaning. American Communication Journal, 5(3). 
İnan, H., \& Kaya, M. (2017). Determining the opinions of physical education teacher candidates about using concept cartoons in education. Journal of Human Sciences, 14(3), 2666-2676. doi:10.14687/jhs.v14i3.4506

Kabapinar, F. (2005). Effectiveness of Teaching via Concept Cartoons from the Point of View of Constructivist Approach. Kuram ve Uygulamada Eğitim Bilimleri. 5 (1).

Kabapınar, F. (2007). Fen Öğretiminde Kavram Karikatürleri: Oluşturmac1 Bir Öğretim Yöntemi, A.Oktay and Ö.P. Unutkan (Ed.) İlköğretim Çağma Genel Bir Bakış (ss.243-264). İstanbul: Morpa Kültür Yayınlar1

Keogh, B., Naylor, S. \& Wilson, C. (1998). Concept cartoons: a new perspective on physics education. Physics Education, 33 (4), 219-224.

Keogh, B., \& Naylor, S. (2000). Teaching and Learning in Science Using Concept Cartoons: Why Dennis Wants to Stay in at Playtime. Investigating: Australian Primary and Junior Science Journal, 16(3), 10-14.

Keogh, B. \& Naylor, S. \& de Boo, M. \& Feasey, R. (2001). (Ed: B, Helgard) Research in $\quad$ Science Education- Past, Present and Future, Formative Assesment Using Concept Cartoons: Initial Teacher Training in The UK. Hingham, USA: Kluwer Academic Publishers.

Long, S. \& Marson, K. (2003). Concept cartoons. Hands on Science, 19(3), 22-24.

Martinez, Y. M. (2004). Does The K-W-L Reading Strategy Enhance Student Understanding in Honors High School Science Classroom?. (Unpublished masters thesis). Fullerton: California State University

Morris, M., Merritt, M., Fairclough, S., Birrell, N. \& Howitt, C. (2007). Trialing concept cartoons in early childhood teaching and learning of science. The Journal of the Australian Science Teachers Association, 53 (2), 42-45.

Oruç, Ş. (2010). Sosyal bilgiler öğretiminde mizah kullanımının öğrencilerin akademik başarılarına ve tutumlarına etkisi. Mehmet Akif Ersoy Üniversitesi Sosyal Bilimler Enstitüsü Dergisi.2 (3).

Ören, F. Ş., \& Meriç, G. (2014). Seventh Grade Students' Perceptions of Using Concept Cartoons in Science and Technology Course. International Journal of Education in Mathematics, Science and Technology, 2(2). 116-136.

Özel, E., Bayındır, N., Gökçe, M., Özel, A. (2014). Öğretmen adaylarının karikatürlerle eğitim sorunlarını alg1lama düzeyleri. International Periodical for the Languages, Literature and History of Turkish or Turkic. 9(3), 1085-1092.

Özer, A.,2004. Karikatür ve Eğitim. Bilim ve Akln Aydmluğnda Eğitim Dergisi, 84, 19-25.

Roesky, H.W. \& Kennepohl, D. (2008). Drawing attention with chemistry cartoons. Chemistry for Everyone, 85 (10), 1355-1360.

Seçgin, G., Yalvaç, G. \& Çetin, T. (2010). İlköğretim 8. sınıf öğrencilerinin karikatürler aracillğıyla çevre sorunlarına ilişkin algıları. International Conference on New Trends in Education and Their Implications. 391-39

Stephenson, P. \&Warwick, P. (2002). Using soncept caroons to progression in students' understanding of light. Physics Education, 37 (2), 135-141.

Yıldırım, A. \& Şimşek, H. (2013). Sosyal Bilimlerde Nitel Araştırma Yöntemleri.Ankara: Seçkin Yayıncilık. 
İnan, H., \& Kaya, M. (2017). Determining the opinions of physical education teacher candidates about using concept cartoons in education. Journal of Human Sciences, 14(3), 2666-2676. doi:10.14687/ihs.v14i3.4506

\section{Appendix}

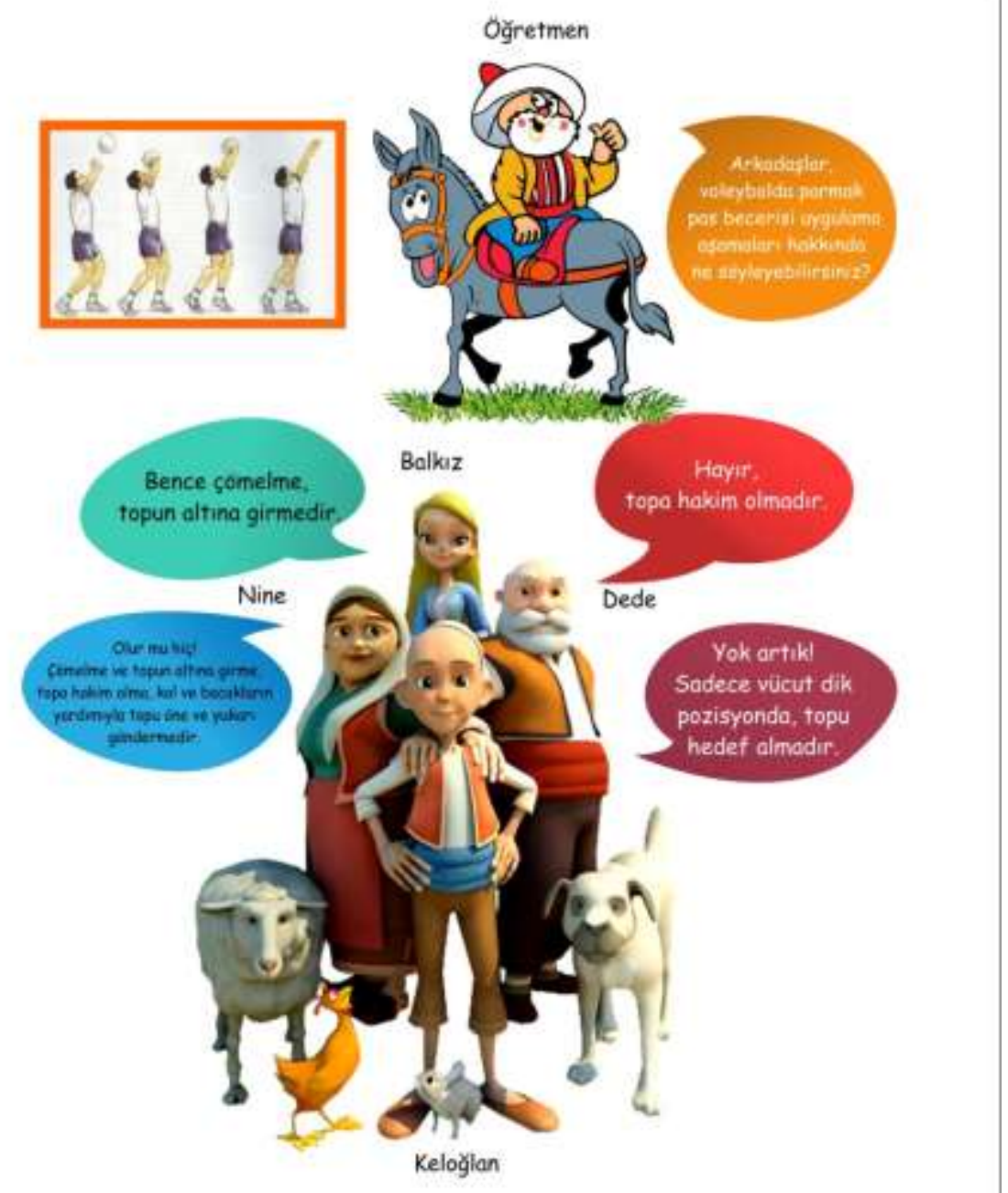

Keloğlan, Balkuz, Nine ve Dede, oğretmenlerinin sorduğu soruyu tartıșmaktadir. Sizce doğru cevabı kim ya da kimler vermiștir?
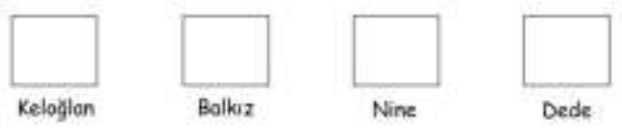

Boyle düsünmenizin sebebi Nedir?

ANNEX-1 Example of concept caricature in the form of working leaf applied in Physical Education 